\title{
Effects of Watertable and Fertilizer Management on Susceptibility of Tomato Fruit to Chilling Injury
}

\author{
Georges T. Dodds ${ }^{1}$, Leif Trenholm², and Chandra A. Madramootoo ${ }^{3}$ \\ Department of Agricultural and Biosystems Engineering, Faculty of Agricultural and Environmental \\ Sciences, Macdonald College of McGill University, 21111 Lakeshore Road, Sainte Anne-de-Bellevue, \\ Que., Canada, H9X 3 V9
}

\begin{abstract}
Additional index words. field lysimeters, subirrigation
Abstract. In a 2-year study (1993-1994), 'New Yorker' tomato (Lycopersicon esculentum Mill.) plants grown in field lysimeters were subjected to four watertable depth (WTD) treatments $(0.3,0.6,0.8$, and $1.0 \mathrm{~m}$ from the soil surface) factorially combined with 5 potassium/calcium fertilization combinations. Mature-green fruit from four replicates of each treatment were stored at $5 \mathrm{C}$ for 21 days, and fruit color was monitored with a tristimulus colorimeter. Fruit were subsequently allowed to ripen at $20 \mathrm{C}$ for 10 days, at which time chilling injury was assessed on the basis of delayed ripening and area of lesions. Potassium and calcium applied in the field had no effect on chilling tolerance of the fruit. In the drier year (1993), shallower WTD treatments generally yielded fruit that changed color less during chilling and were more chilling-sensitive based on delayed ripening. In the wetter year, differences in color change and chilling tolerance between WTD, if any, were small. Over both years, lesion area varied with WTD, but not in a consistent manner. Based on these results, we suggest that differences in water availability should be considered when studying tomato fruit chilling.
\end{abstract}

With the exception of studies on bitter pit and scald in apple and other pome crops (Monselise and Goren, 1987; Sharples, 1985), there have been few reports on the effects of preharvest conditions and treatments on storability and chilling sensitivity of fruit. However, some work on tomato fruit is scattered through the literature. Late-season crops of tomato (Lycopersicon esculentum Mill.) have long been known to be more susceptible to chilling injury than early season crops (Kidd and West, 1933; Rosa, 1926). More recent studies have supported this conclusion (Dodds, 1991). This phenomenon was attributed to the initiation and accumulation of chilling damage in the field at temperatures below 10C (Barger et al., 1952). Saltveit and Cabrera (1987) showed that the higher the fruit temperature at harvest, the higher the chilling damage after storage at $7 \mathrm{C}$ and subsequent ripening. Morris (1954) showed that susceptibility to chilling injury was best correlated to the number of hours below $15.6 \mathrm{C}$ in the field, during the week before harvest. Dodds et al. (1991) showed that tomato surface color change during chilling was reduced as the number of hours below 15.6C in the $200 \mathrm{~h}$ (8.3 days) before harvest increased.

Dipping or vacuum infiltration of harvested fruit with calcium or potassium chloride before cold storage has shown limited promise in reducing chilling injury (Kader and Morris, 1975; Moline, 1980). The only studies on the effects of soil fertility on field-grown tomato chilling tolerance date from the early 1930s. Wardlaw and McGuire (1932) first observed that tomato fruit grown in Trinidad on newly cleared hillsides were more tolerant to chilling than those grown on the long exploited plains. Further, supplementation of normal fertilizer applications with ammonium sulfate increased chilling-related wastage by about $50 \%$, while

Received for publication 31 July 1995. Accepted for publication 30 Nov. 1995. The authors acknowledge the financial assistance of the Natural Sciences and Engineering Research Council of Canada (NSERC). We thank the staff of the Macdonald College Horticulture Research Station and A. Rajabipour, R. Zareifard, and S. Abou-Rjeili for assisting with some of the field and laboratory work. PlastiDrain of Québec is thanked for supplying some of the pipe materials. P.M. Ludford, Cornell Univ. is thanked for reviewing the manuscript. The cost of this paper was defrayed in part by the payment of page charges. Under postal regulations, this paper therefore must be hereby marked advertisement solely to indicate this fact. ${ }^{1}$ Postdoctoral fellow.

${ }^{2}$ Graduate student.

${ }^{3}$ Professor of agricultural and biosystems engineering. supplementation with either superphosphate or potassium chloride reduced wastage by about $40 \%$ (Wardlaw and McGuire, 1933).

Morris (1953) noted that rainy days followed by cool cloudy days before harvest promote chilling injury. However sprinklers did not have this effect in good weather, indicating that this was an effect not only of rain, but of other factors as well. Grapefruit harvested during periods of water stress were less susceptible to chilling injury during postharvest storage (Kawada et al., 1978). The effects of irrigation frequency and method on chilling susceptibility of tomatoes have not been studied.

By raising the level of subsurface agricultural drainage outlets which would otherwise flow into lakes or streams, water can be kept in the field. Such watertable management systems require flat topography, coarser textured soils, an impermeable soil layer at $1^{-2} \mathrm{~m}$ depth, and the presence or installation of a pipe drainage system. Such systems are cheaper than sprinkler systems (Doty, 1983), conserve water (Stone and Williams, 1992), and reduce nitrate leaching (Madramootoo et al., 1993; Kalita and Kanwar, 1993).

This study compares the effects of subirrigation at four watertable depths in combination with five calcium/potassium fertilization rates on chilling injury susceptibility of tomato fruit.

\section{Materials and Methods}

Site and layout of experiment. The experiment was conducted at the Macdonald College Horticulture Research Station of McGill Univ., Sainte Anne-de-Bellevue, Que. 'New Yorker' tomato plants were grown outdoors in $0.40-\mathrm{m}$ diameter polyethylene cores (lysimeters), 1.2-m deep, containing a Courval sandy loam (85\% sand, $15 \%$ clay) packed to a bulk density of $1.1 \mathrm{t} \cdot \mathrm{m}^{-3}$ (Fig. 1 ). 80 lysimeters were divided into four groups of 20 , one for each watertable depth. Lysimeters were centered $1.0 \mathrm{~m}$ apart both rowand lengthwise within a group, and groups were $2.0 \mathrm{~m}$ apart. Guard rows, with the same $1.0 \mathrm{~m}$ spacing were planted between and around the periphery of the groups. The water control chambers were the same size as the lysimeters, and were equipped with overflow pipes of different lengths $(0.25,0.50,0.75$, and $1.0 \mathrm{~m}$ from the soil surface of the attached lysimeters (Fig. 1). Each chamber controlled the watertable in five lysimeters. The bottom of each overflow pipe was connected to a drainage pipe. Details of 


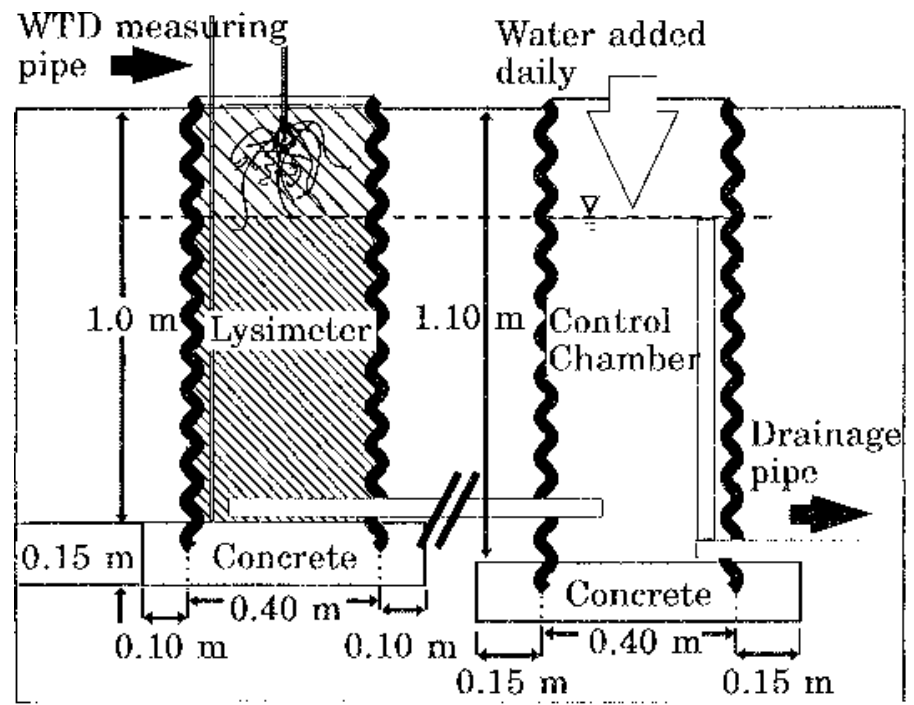

Fig. 1. Diagram of the lysimeter and watertable control tank.

the lysimeter design have been presented elsewhere (Madramootoo et al., 1993). Each lysimeter was equipped with a piezometer to allow monitoring of the actual watertable depth (Fig. 1). The average measured experimental watertable depths were $0.3,0.6$, 0.8 , and $1.0 \mathrm{~m}$ in 1993 and 1994.

These four watertable depths (WTD) treatments were factorially combined with five fertilizer treatments. Potassium was applied to the soil as $\mathrm{K}_{2} \mathrm{O}$, which also contained $10 \%$ magnesium (w/w) (Nutrite; Brossard, Que.), while calcium was applied as a 1.0\% (w/ v) $\mathrm{CaCl}_{2}$ (Sigma, St. Louis, Mo.) foliar spray, roughly $250 \mathrm{~kg} \mathrm{Ca} /$ ha/application, starting when the first fruit were $10 \mathrm{~mm}$ in diameter until harvest, on cloudless days.

Potassium and $\mathrm{Ca}$ were applied in five different combinations (Table 1). Before fertilization the soil contained roughly $0.1 \mathrm{~g} \mathrm{~K} /$ $\mathrm{kg}$ soil and $1.6 \mathrm{~g} \mathrm{Ca} / \mathrm{kg}$ soil. On the eve of planting, $\mathrm{N}, \mathrm{P}$, and $\mathrm{K}$ fertilizers were manually applied to the soil surface and mixed to a depth of about $50 \mathrm{~mm}$. In both years, $\mathrm{P}$ was applied as rock phosphate (Engrais Naturels; McInnes, St. Bruno, Que.) at a rate of $71 \mathrm{~kg} \mathrm{P} / \mathrm{ha}$, and $\mathrm{N}$ was applied as ammonium nitrate (Cargill, London, Ont.) at $90 \mathrm{~kg} \mathrm{~N} / \mathrm{ha}$, with an additional $45 \mathrm{~kg} \mathrm{~N} / \mathrm{ha}$ broadcast 3 weeks later. These rates were based on prior soil testing and local recommendations (Conseil des productions végétales du Québec, 1978).

Plant growth. 'New Yorker' tomato seeds (W.H. Perron, Laval, Que.) were planted in potting medium (14 Apr. 1993 and 15 Apr. 1994). After 1 week seedlings were transplanted to cell packs containing potting medium and watered with a solution of transplant fertilizer containing $1.0 \mathrm{~g} \mathrm{~N}, 2.6 \mathrm{~g} \mathrm{P}$, and $0.8 \mathrm{~g} \mathrm{~K}$ per liter + micronutrients (Nutrite). Thereafter, seedlings received a solution of fertilizer containing $0.5 \mathrm{~g} \mathrm{~N}, 0.25 \mathrm{~g} \mathrm{P}$, and $0.4 \mathrm{~g} \mathrm{~K}$ per liter, every
2 weeks. Seedlings were hardened outdoors during the week before planting.

A single seedling was transplanted to each lysimeter and to guard row sites on 5 June 1993 and on 30 May 1994. Each seedling received 0.5 liter of the above transplant fertilizer. Any damaged plants were replaced within 1 week after planting. Flowers or flower buds were removed from the plants for 4 weeks after planting.

Mature green fruit were harvested between 1300 HR and 1400 HR, 11 and 23 Aug. 1993 and 7 Aug. 1994. Field air temperature was between 28C and 30C for all harvests. For Harvest 1 in 1993, 4 fruit were harvested per plant for all four watertable treatments. However, for Harvest 2 no fruit were available from plants grown on the $1.0 \mathrm{~m}$ watertable treatment. Harvest 2 was not independent of Harvest 1 , since fruit were those remaining and having matured after Harvest 1. In 1994, three fruit were harvested per plant for all watertable treatments. We selected only fruit of marketable size (maximum equatorial diameter $>50 \mathrm{~mm}$ ), showing no blossom end rot, sunscald, cracking, scarring or other damage, and with minimal catfacing.

Color measurements during cold storage. Mature green fruit were wiped clean with a cloth and placed blossom end up on plastic trays $(0.3 \times 0.4 \mathrm{~m})$. For all harvests, processing of these and other fruit took 4-6 h, during which all fruit remained at roughly $25 \mathrm{C}$. Thus, effects of prestorage conditioning at lower temperatures, such as reported by Saltveit (1991), were not an issue. Fruit were stored for 21 days at 5C in 1993, and 1994. Fruit color was measured roughly $10 \mathrm{~mm}$ from the blossom scar of the fruit before storage, after $36 \mathrm{~h}$ storage, and at $24-\mathrm{h}$ intervals thereafter, using an $8 \mathrm{~mm}$ aperture chroma meter (CR 300; Minolta, Mississauga, Ont.), in $\mathrm{L}^{*}, \mathrm{a}^{*}, \mathrm{~b}^{*}$ mode. $\mathrm{L}^{*}, \mathrm{a}^{*}, \mathrm{~b}^{*}$ values were converted to a tomato color index (Col; Hobson, 1987)

$\mathrm{Col}=2000 \mathrm{a} / \mathrm{L} \sqrt{\mathrm{a}^{2}+\mathrm{b}^{2}}$

The color change during chilling was quantified for each fruit using the percent change in $\mathrm{Col}$ from the initial value $(\% \Delta \mathrm{Col})$, calculated for different durations $(x$ in $h)$ of chilling:

$\% \Delta \mathrm{Col} \mathrm{x} \mathrm{h}=100\left(\mathrm{Col}_{\times \mathrm{h}}-\mathrm{Col}_{0 \mathrm{~h}}\right) / \mathrm{Col}_{0 \mathrm{~h}}$

Examination of linear residual plots indicated that a polynomial model was appropriate. The $\% \Delta \mathrm{Col}$ was averaged $(n=3$ or 4$)$ for each plant, and curvilinear regressions were fitted to the $\% \Delta \mathrm{Col}$ data according to the model

$\% \Delta \mathrm{Col}=\beta_{1} \cdot \mathrm{HOC}+\beta_{2} \cdot\left(\mathrm{HOC}-\mathrm{HOC}_{\mathrm{avg}}\right)^{2}$

where: $\mathrm{HOC}=$ hours of chilling, $\mathrm{HOC}_{\mathrm{avg}}=$ average hours of chilling at which measurements were made, and $\beta_{1}, \beta_{2}=$ linear and quadratic regression coefficients. The $\mathrm{HOC}-\mathrm{HOC}_{\text {avg }}$ terms reduced multicolinearity between the linear and quadratic terms from $r \approx 0.97$ to $|r|<0.18$.

Multiple analysis of variance (MANOVA) of the resulting regression coefficients was followed by canonical variates (CV) analysis as described in detail in Yourstone and Wallace (1990) and Dodds et al. (1991). Honestly significant intervals $(\alpha=0.05)$

Table 1. Treatments to which tomato plants were subjected.

\begin{tabular}{lccc}
\hline \hline $\begin{array}{l}\text { Watertable } \\
\text { depth }(\mathrm{m})\end{array}$ & $\begin{array}{c}\text { Fertilizer } \\
\text { treatment }(\mathrm{K} / \mathrm{Ca})\end{array}$ & $\begin{array}{c}\text { Potassium applied } \\
(\mathrm{kg} / \mathrm{ha})\end{array}$ & $\begin{array}{c}\text { Calcium applied } \\
(250 \mathrm{~kg} / \mathrm{ha} / \text { application })\end{array}$ \\
\hline & Low/low & 0 & None \\
$0.3 \mathrm{~m}$ & Low/high & 0 & Spraying interval, 1 week \\
$0.6 \mathrm{~m}$ & Medium/medium & Spraying interval, 2 weeks \\
$0.8 \mathrm{~m}$ & High/low & 333 & None \\
$1.0 \mathrm{~m}$ & High/high & 332 & Spraying interval, 1 week
\end{tabular}

$\overline{{ }^{\mathrm{z}} \text { Medium/medium levels for potassium and calcium were those recommended by the Conseil des }}$ productions végétales du Québec (1978). 
were calculated for each CV (Andrews et al., 1980), whose experimental error standard deviation was normalized to 1 , according to the equation

$\mathrm{HSI}=\mathrm{CV} \pm q \cdot 1 / 2 \sqrt{ } n$

where $q=$ studentized range statistic (Duncan, 1955) based on the degrees of freedom of the data, selected level of significance, and number of treatments being compared, and $n=$ number of replicates in the treatment for which the mean is calculated. This interval was used to determine differences by treatment. For all comparisons a dimensionality of 1 , but not of 2 , was significant. Thus, comparisons were made exclusively between first CV. Overall, the greater the value of the first $\mathrm{CV}$, the greater the color change during chilling.

Chilling injury assessment . Chilling damage was assessed on the basis of delay in ripening and area of lesions on the fruit. After storage, fruit were allowed to ripen at $20 \mathrm{C}$ for 10 days. The area of lesions was expressed as a percentage of total fruit surface area and scored for the stem scar region, blossom scar region, and other sites on the fruit surface. While the percent area injured was always less than $10 \%$ of the total fruit surface area, extending the ripening period tended to lead to proliferation of microorganisms and masking of differences between treatments. Fruit surface area was calculated as

Area $=\pi\left[\left(\operatorname{maxED}{ }^{2}+\operatorname{minED}\right)+\text { height }\right]^{2} / 4$

where height is the height of the fruit from stem scar to blossom scar, maxED is the maximum equatorial diameter, and minED is the minimum equatorial diameter.

The fruit were also visually scored for stage of ripening reached: 0 for mature green, 10 for breaker, 20 for turning, 30 for early pink, 45 for pink, 75 for red, and 100 for full ripe or overripe, corresponding roughly to the percentage of the fruit ripened. Percent fruit surface damaged and ripening stage were averaged over the three (Harvest 3) or four fruit (Harvest 1 and 2) from each plant/ lysimeter ( 60 or 80 fruit/WTD). Resulting averages were subjected to an arcsin transformation before univariate analysis of variance. Fertilizer $($ FERT) effects and FERT $\times$ WTD interactions were not significant (Table 2), so data were pooled across fertilizer treatments and compared by WTD alone.

Field measurements. Rainfall, class A pan evaporation, wind run, and minimum and maximum air and water temperatures were measured daily at the site. Daily crop evapotranspiration $\left(\mathrm{ET}_{\mathrm{c}}\right)$ was calculated by multiplying the pan evaporation by a pan constant $\left(\mathrm{k}_{\mathrm{p}}\right)$ and a crop consumptive use coefficient $\left(\mathrm{k}_{\mathrm{c}}\right)$. Values for $\mathrm{k}_{\mathrm{p}}$ were computed daily according to American Society of Civil Engineers (1990) and ranged from 0.67 to 0.82 . The $\mathrm{k}_{c}$ values were taken from Doorenbos and Kassam (1979). Mean soil moisture in the top 0.6 $\mathrm{m}$ of the soil was measured by time domain reflectometry (Topp and Davis, 1985).

\section{Results and Discussion}

Fertilizer effects. No significant differences in color change, injury expressed as fruit lesions, or ripening were found among the various fertilizer combinations in any of the three harvests (Table 2).

Wardlaw and McGuire (1933) showed a $40 \%$ improvement in chilling tolerance when additional calcium superphosphate or potassium chloride was applied to field-grown tomatoes normally receiving only $27 \mathrm{t} / \mathrm{ha}$ of manure. Such effects were not apparent in the present work. However, soil type, climate, mode of irrigation, fertilization (inorganic vs. organic), and study site (lysimeters vs. open field), were different in our study from those of Wardlaw and McGuire (1933).

Weather patterns and water relations. During 1993 and 1994, there was above average precipitation in June. June rainfall was about 100\% (1993) and 125\% (1994) higher than the local 30-year average, and 30\% higher in 1994 than 1993 (Table 3). Soil moisture in the top $0.6 \mathrm{~m}$ of the soil was $2.4 \%$ to $6.3 \%$ higher in 1994 than 1993, and close to field capacity for the two shallower WTD (Table 4). However, roughly two thirds of the June 1993 rain came during vegetative growth (Fig. 2), while roughly two thirds of June 1994 rain occurred during flowering, including two highintensity storms of over $35 \mathrm{~mm}$. The physical damage and shortterm waterlogging from these rains likely contributed to the greatly reduced yields and stem weight at harvest in 1994. In pot experiments, Lopez and del Rosario (1983) showed that 10 days of flooding at flowering reduced tomato fruit set, yield (fruit/plant or weight), and seeds per locule more than the same flooding applied during either the seedling or fruit development stages. Orchard and Jessup (1984) showed similar effects of waterlogging at equivalent phenological stages of sunflower and sorghum. Waterlogging in the field at the second flower-cluster stage resulted in anaerobic soil conditions to a depth of $0.2 \mathrm{~m}$ for $24 \mathrm{~h}$. This led to $15 \%$ of tomato plants wilting (vs. $4 \%$ for nonirrigated), and $40 \%$ yield reductions (Hubbell et al., 1979).

Table 2. Differences in color change, percentage of fruit surface damaged, and ripeness for fruit of tomato plants grown in different watertable depths (WTD) and potassium-calcium fertilizer combination (FERT) treatments.

\begin{tabular}{|c|c|c|c|c|c|c|c|c|}
\hline \multirow[b]{2}{*}{ Year } & \multirow[b]{2}{*}{ Harvest no. } & \multirow[b]{2}{*}{ Factor } & \multirow{2}{*}{$\begin{array}{c}\text { Color } \\
\text { change }^{\mathrm{y}}\end{array}$} & \multicolumn{4}{|c|}{ Percentage of fruit surface damaged ${ }^{2}$} & \multirow[b]{2}{*}{ Ripeness $^{\mathrm{y}}$} \\
\hline & & & & Top & Bottom & Side & Total & \\
\hline \multirow[t]{8}{*}{$\overline{1993}$} & 1 & MODEL & --- & $*$ & NS & $*$ & $*$ & $* *$ \\
\hline & & WTD & $* *$ & $* *$ & NS & $* *$ & $* *$ & $* *$ \\
\hline & & FERT & NS & NS & NS & NS & NS & NS \\
\hline & & WTD $\times$ FERT & NS & NS & NS & NS & NS & NS \\
\hline & 2 & MODEL & --- & NS & NS & NS & NS & NS \\
\hline & & WTD & $*$ & $*$ & NS & NS & $*$ & $*$ \\
\hline & & FERT & NS & NS & NS & NS & NS & NS \\
\hline & & $\mathrm{WTD} \times \mathrm{FERT}$ & NS & NS & NS & NS & NS & NS \\
\hline \multirow[t]{4}{*}{1994} & 3 & MODEL & --- & NS & NS & NS & NS & $* *$ \\
\hline & & WTD & NS & NS & NS & $*$ & $*$ & $* *$ \\
\hline & & FERT & NS & NS & NS & NS & NS & NS \\
\hline & & WTD $\times$ FERT & NS & NS & NS & NS & NS & NS \\
\hline
\end{tabular}

${ }^{\mathrm{z}}$ Significance based on ANOVA.

'Significance based on Wilks' Lambda.

Ns,*,** Nonsignificant or significant at $P \leq 0.05$ or 0.0005 , respectively. 
Table 3. Precipitation at study site in 1993, 1994, and 30 year average from Dorval airport meteorological station, $10 \mathrm{~km}$ east of study site.

\begin{tabular}{lccc}
\hline \hline & \multicolumn{3}{c}{ Precipitation (mm) } \\
\cline { 2 - 4 } & \multicolumn{3}{c}{ Avg, 30-year } \\
Period & 1993 & 1994 & $(1961-1990)$ \\
\hline June & 133.5 & 174.6 & 78.0 \\
July & 83.2 & 55.2 & 85.6 \\
1-9 Aug. & --- & 46.9 & 31.2 \\
$1-23$ Aug. & 24.9 & --- & 71.5 \\
\hline
\end{tabular}

The fact that the $1.0 \mathrm{~m}$ WTD showed similar yield and stem weight in 1993 and 1994, while shallower WTD showed reductions ranging from $45 \%$ to $880 \%$ further confirms that waterlogging was likely a contributing factor to these differences (Table 4). In 1993, yield and stem weight were highest at the $0.6 \mathrm{~m}$ WTD, slightly lower at the $0.3 \mathrm{~m} \mathrm{WTD}$, and increasingly lower at the 0.8 and $1.0 \mathrm{~m} \mathrm{WTD}$. While plant water stress was not measured and a characteristic soil moisture curve is not available for this soil, it may be inferred that in 1993 watertable effects were predominantly related to moisture deficits at deeper WTD. On the other hand, in 1994, yield increased with increasing WTD, suggesting that watertable effects were predominantly related to moisture excesses at shallower WTD.

Morris (1954) and Barger et al. (1955) showed that, while fruit from later harvests were generally more prone to chilling injury, the conditions in the week before harvest, particularly the number of hours below $15.6 \mathrm{C}$, were important in determining susceptibility of mature green fruit to chilling injury. In California, fruit with less than $95 \mathrm{~h}$ below $15.6 \mathrm{C}$ in the week before harvest seldom developed chilling injury symptoms, whereas those with over 135 $\mathrm{h}$ below 15.6C showed a great deal of chilling injury (Morris, 1954). In New York, fruit subjected to close to $100 \mathrm{~h}$ below 15.6C in the $200 \mathrm{~h}$ before harvest, showed significantly reduced color change during cold storage and greater subsequent chilling damage, compared with fruit of an earlier harvest which sustained about 50 h below 15.6C (same cultivar, same site; Dodds et al., 1991). In the present case, the number of hours below $15.6 \mathrm{C}$ were well below any of the levels of preharvest chilling mentioned above (Table 5) This should not have been a factor in the differences in sensitivity encountered between harvests.

Morris (1953) found that rainy days followed by cool, cloudy days before harvest promoted chilling injury. Differences in the conditions in the week before harvest between Harvest 1 and Harvest 2 were rather minor (Table 5). However, consistent with 1994 being a wetter year than 1993, Harvest 3 received 4.6-fold more rain than Harvest 1 in the week before harvest (9.4-fold more rain in the 8 days before harvest) (Fig. 2, Table 4). There was a surplus of $5.6 \mathrm{~mm}$ of rain over evapotranspiration before Harvest 3 , whereas Harvest 1 was preceded by a deficit of $15.8 \mathrm{~mm}$ of rain to evapotranspiration. Both the hours of effective sunlight and wind run in the week before harvest were less for Harvest 3 than for Harvest 1 . The week before Harvest 3 had more precipitation, a greater surplus of rain over evapotranspiration, was more overcast, and less windy than for Harvest 1. This was expected to have contributed to greater damage due to microrganisms and greater delay in ripening due to chilling in 1994 . However this was not the case; damage and delay in ripening were greater for Harvest 1 than Harvest 3 (Table 6).

At Harvest 1, all fruit that were mature-green or more ripe were removed. Harvest 2 was taken from the same plants, when sufficient numbers of the remaining immature fruit had developed to the mature green stage. Percentages of fruit harvested in Harvest 1 were $28 \%, 16 \%$, and $30 \%$ of the total season's harvest, while the mean final shoot weights were 480,827 and $424 \mathrm{~g}$ fresh weight for the $0.3,0.6$, and $0.8 \mathrm{~m} \mathrm{WTD,} \mathrm{respectively} \mathrm{(Table} 4$ ). Thus, the relative fruit load on plants differed before and after Harvest 1, and may have been a factor influencing fruit chilling susceptibility in Harvest 2 fruit. Comparisons based strictly on soil moisture effects can be made between Harvests 1 and 3, but not between Harvest 2 and other harvests.

Thus, any effects of field conditions on chilling injury appear to be predominantly those of WTD and precipitation as they affected soil moisture. In the drier 1993, shallower WTD treatments supplied water by upward flux, which would have been unavailable at deeper WTD treatments, whereas in the wetter 1994, deeper WTD treatments provided sufficient drainage to alleviate waterlogging experienced at shallower WTD.

Chilling injury and color changes during storage. For harvests 1 and 2 , chilling injury measured as delay in ripening after 10 days at 20C was significantly different among the WTD treatments (Table 6). For Harvest 1, fruit ripened roughly to the breaker, early pink, late pink, and red ripe stages, for the $0.3,0.6,0.8$ and $1.0 \mathrm{~m}$ WTD treatments, respectively. Ripeness was also significantly different among WTD treatments for Harvest 2 (Table 6). Again, fruit from the treatment with the least soil moisture (0.8 m WTD) ripened most (midway between pink and red), while those from the shallower WTD $(0.6 \mathrm{~m}$ and $0.3 \mathrm{~m})$ ripened less, but equally (early pink). In 1993, post-chilling ripening increased with increasing depth of the watertable (Table 6). Fruit from plants grown under conditions of lesser soil moisture (or by inference greater water stress) showed greater chilling tolerance than fruit of plants grown at higher soil moisture. Grapefruit harvested during periods of water stress were also less susceptible to chilling injury during postharvest storage (Kawada et al., 1978).

For Harvest 3, in contrast to Harvests 1 and 2, delay in ripening increased with increasing WTD (Table 6). This reversal might be explained if one considers that the stress imparting tolerance is in 1993 a drought stress, increasing with WTD, whereas the stress in 1994 was a waterlogging stress, decreasing with WTD. However, differences in ripening in 1994, while significant, were quite small, all within the range of red to overripe fruit. This might be explained

Table 4. Soil moisture, yield, and plant stem weight at harvest for 1993 and 1994.

\begin{tabular}{|c|c|c|c|c|c|c|}
\hline \multirow{2}{*}{$\begin{array}{l}\text { Watertable } \\
\text { depth (m) }\end{array}$} & \multicolumn{2}{|c|}{$\begin{array}{l}\text { Volumetric soil moisture } \\
\qquad(\%) \text { to } 0.6 \mathrm{~m} \mathrm{depth}\end{array}$} & \multicolumn{2}{|c|}{$\begin{array}{l}\text { Total marketable } \\
\text { yield (fruit/plant) }\end{array}$} & \multicolumn{2}{|c|}{$\begin{array}{l}\text { Stem wt at } \\
\text { harvest }(\mathrm{g})\end{array}$} \\
\hline & 1993 & 1994 & 1993 & 1994 & 1993 & 1994 \\
\hline 0.3 & $33.6 \pm 8.9^{y}$ & $36.0 \pm 8.9$ & $31.6 \pm 6.3$ & $3.8 \pm 0.9$ & $491 \pm 72$ & $69 \pm 49$ \\
\hline 0.6 & $24.5 \pm 6.4$ & $30.8 \pm 6.4$ & $39.8 \pm 6.9$ & $7.8 \pm 2.9$ & $827 \pm 176$ & $341 \pm 81$ \\
\hline 0.8 & $11.1 \pm 4.2$ & $16.2 \pm 4.2$ & $23.3 \pm 4.2$ & $11.2 \pm 3.7$ & $424 \pm 158$ & $230 \pm 42$ \\
\hline 1.0 & $7.1 \pm 3.6$ & $10.3 \pm 2.8$ & $16.8 \pm 3.8$ & $12.8 \pm 4.1$ & $190 \pm 53$ & $206 \pm 46$ \\
\hline
\end{tabular}

${ }^{\mathrm{z}}$ Field capacity is $38 \%$, permanent wilting point $3 \%$.

${ }^{\mathrm{y}}$ Mean \pm standard deviation 


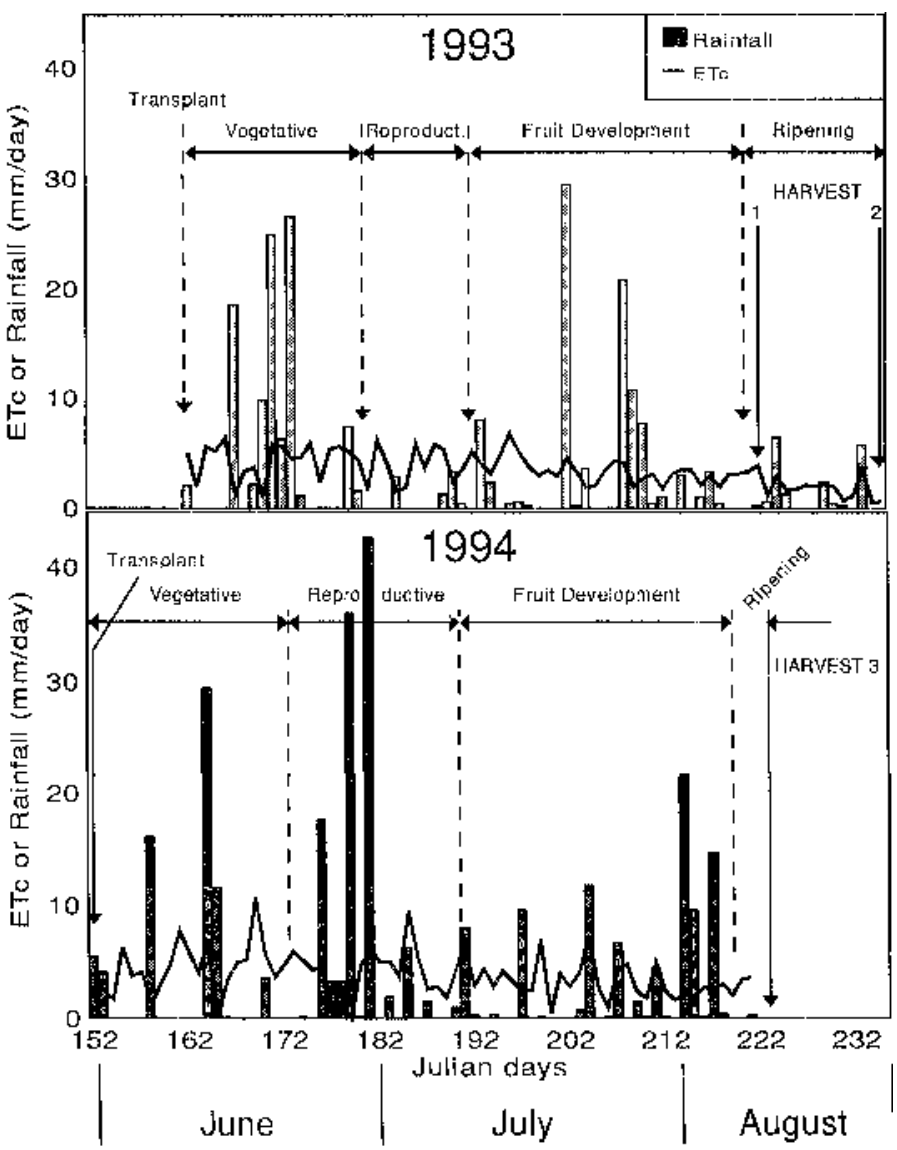

Fig. 2. Precipitation and crop evapotranspiration.

by the different nature of the stress, or by the fact that differences between WTD treatments are less in wet vs. dry years. Using the same lysimeters, Madramootoo et al. (1993) found smaller differences in yield between soybeans grown at different WTD in wet compared to dry years.

For all harvests and all WTD treatments, growth of lesions occurred predominantly on the top (stem scar end) of the fruit, compared with the bottom (blossom end) or other regions of the fruit (Table 6). This was consistent with observations made by Dodds and Ludford (1989).

Growth of lesions on fruit as a measure of chilling injury was significantly different among WTD treatments for the top and total areas surveyed of Harvest 1 and 2 fruit (Table 6). For Harvest 1 fruit, lesion area was significantly greater at the 0.6 and $0.8 \mathrm{~m} \mathrm{WTD}$ than at the two extreme WTD of 0.3 and $1.0 \mathrm{~m}$ (Table 6).

For Harvest 2 the greatest lesion area was found for the $0.3 \mathrm{~m}$ WTD, with the 0.6 and $0.8 \mathrm{~m}$ WTD showing about $20 \%$ less total area. With respect to lesion area and ripening, Harvest 2 showed similar values to Harvest 1 for both 0.6 and $0.8 \mathrm{~m}$ WTD treatments, but lesion area increased $90 \%$ for the shallower $(0.3 \mathrm{~m})$ WTD treatment. For Harvest 3, lesion area showed differences only for the sides and total area of fruit (Table 6). Lesion area of the $1.0 \mathrm{~m}$ WTD fruit was greater than all other WTD combined. Overall both lesion area and delay in ripening were much lower in 1994 than in 1993 (Table 6). Burgis (1970) showed, across several harvests, a consistent inverse relationship between post-chilling ripening of tomatoes and percent of fruit damaged by rot. In our study, for all three harvests, delay in ripening did not parallel lesion area (Table 6 ) or the percent of fruit with rot (data not shown). The differences between our study and that of Burgis (1970) may be related to the
Table 5. Environmental conditions during the week before harvest.

\begin{tabular}{lccc}
\hline \hline & \multicolumn{3}{c}{ Harvest } \\
\cline { 2 - 4 } & 1 & 2 & 3 \\
Conditions & (11 Aug. & (23 Aug. & (9 Aug. \\
Hours below & $1993)$ & $1993)$ & $1994)$ \\
10C (50F) & & & \\
15.6C (60F) & 0 & 10 & 15 \\
Rainfall (mm) & 45 & 38 & 58 \\
Evapotranspiration (mm) & 20.3 & 8.8 & 25.2 \\
Rain-ET & -15.8 & 11.4 & 19.6 \\
Hours effective sunlight & 59.3 & -2.6 & +5.6 \\
Wind run (km) & 3047 & 60.9 & 55.4 \\
& & 3439 & 2378 \\
\hline
\end{tabular}

additional factors of soil moisture and fertilization level in our study.

Dodds et al. (1991) showed that fruit of tolerant vs. susceptible cultivars, and fruit stored at $5 \mathrm{C}$ vs. $2 \mathrm{C}$ showed greater $\% \Delta \mathrm{Col}$ during chilling. Fruit which remained undamaged after chilling vs. those showing severe rot tended to show greater $\% \Delta \mathrm{Col}$. Thus, $\% \Delta \mathrm{Col}$ was generally greatest for treatments or varietal characteristics, which led to reduced chilling injury. In our study, fruit from Harvests 1 and 2, showed significantly different $\% \Delta$ Col between WTD treatments, pooled across fertilizer treatments, but not fruit from Harvest 3 (Table 6). For Harvest 1, while $\% \Delta$ Col increased with WTD treatments, delay in ripening decreased. However, for Harvest 2 fruit the $\% \Delta \mathrm{Col}$ was greatest for the fruit of $0.6 \mathrm{~m}$ WTD plants and about $20 \%$ less for fruit from the 0.3 and $0.8 \mathrm{~m}$ WTD treatments (Table 6 ). The $\% \Delta \mathrm{Col}$ for Harvest 3 fruit tended to be larger for the two deeper watertable depths; however, $\% \Delta \mathrm{Col}$ during chilling was much less than in either of the previous harvests. Though differences in $\% \Delta \mathrm{Col}$ were not significant, the trend was exactly the opposite to that observed in Harvest 1. This difference in response to WTD might be related to the different nature of the stress imposed by varying the WTD in 1993 vs. 1994. Drought stress appeared to generally promote chilling tolerance as estimated by delay in ripening. Waterlogging stress appeared to have a similar effect on chilling tolerance, but of much lesser magnitude. In either case, further studies are required to more firmly establish any relationship between field water stresses and chilling tolerance.

When $\% \Delta \mathrm{Col}$ for all three harvests is compared with the area of lesions no observable trend is apparent. Dodds et al. (1991) found that $\% \Delta \mathrm{Col}$ was a poor predictor of chilling tolerance among 44 lines/ cultivars, when tolerance was based predominantly on severity of rot.

Susceptibility of tomato fruit to chilling injury appeared to be influenced mainly by soil moisture, as effects of WTD and precipitation greatly overshadowed any effect of fertilization rate. In a relatively dry year (1993), shallower WTD which maintained higher soil moisture levels generally led to greater susceptibility to chilling injury based on delayed ripening, than deeper WTD treatments. However, in a wet year, when deeper WTD treatments alleviated waterlogging, differences by WTD were not clear. We conclude that differences in water availability during development should be considered when studying susceptibility of tomato fruit to chilling injury.

\section{Literature Cited}

Andrews, H.P., R.D. Snee, and M.H. Sarner. 1980. Graphical display of means. Amer. Stat. 34:195-199

American Society of Civil Engineers. 1990. Evapotranspiration and irrigation requirements, p. 108-109. In: M.E. Jensen, R.D. Burman, and 
Table 6. Color change of tomato fruit during chilling, along with percentage of fruit surface damaged, and ripeness after 10 days at 20C, for different watertable depths for three harvests.

\begin{tabular}{|c|c|c|c|c|c|c|c|c|}
\hline \multirow[b]{2}{*}{ Year } & \multirow{2}{*}{$\begin{array}{c}\text { Harvest } \\
\text { no. }\end{array}$} & \multirow{2}{*}{$\begin{array}{l}\text { Watertable } \\
\text { depth (m) }\end{array}$} & \multirow{2}{*}{$\begin{array}{c}\text { Color } \\
\text { change }^{\mathrm{y}}\end{array}$} & \multicolumn{4}{|c|}{$\begin{array}{c}\text { Lesion area }{ }^{\mathrm{z}} \\
(\% \text { of fruit surface affected })\end{array}$} & \multirow{2}{*}{$\begin{array}{r}\text { Ripening } \\
\text { stage }^{2}\end{array}$} \\
\hline & & & & Top & Bottom & Side & Total & \\
\hline \multirow[t]{7}{*}{$\overline{1993}$} & 1 & 0.3 & $5.0 \mathrm{c}$ & $3.86 \mathrm{~b}$ & $0.03 \mathrm{~b}$ & $<0.01 b$ & $3.89 b$ & $10.0 \mathrm{c}$ \\
\hline & & 0.6 & $6.2 b$ & $4.69 a$ & $0.14 \mathrm{a}$ & $0.17 \mathrm{a}$ & $5.00 \mathrm{a}$ & $37.3 b$ \\
\hline & & 0.8 & $6.8 \mathrm{ab}$ & $4.94 a$ & $0.08 \mathrm{ab}$ & $0.08 \mathrm{a}$ & $5.10 \mathrm{a}$ & $50.2 b$ \\
\hline & & 1.0 & $7.5 \mathrm{a}$ & $3.66 \mathrm{~b}$ & $0.07 \mathrm{ab}$ & $0.01 b$ & $3.74 b$ & $84.2 \mathrm{a}$ \\
\hline & 2 & 0.3 & $4.9 b$ & $5.56 \mathrm{a}$ & $1.19 \mathrm{a}$ & $0.58 \mathrm{a}$ & $7.42 \mathrm{a}$ & $30.4 \mathrm{~b}$ \\
\hline & & 0.6 & $6.4 \mathrm{a}$ & $3.86 \mathrm{~b}$ & $0.96 \mathrm{a}$ & $0.93 \mathrm{a}$ & $5.75 b$ & $30.7 b$ \\
\hline & & 0.8 & $5.1 \mathrm{~b}$ & $4.07 \mathrm{ab}$ & $0.88 \mathrm{a}$ & $0.62 \mathrm{a}$ & $5.58 \mathrm{ab}$ & $58.7 \mathrm{a}$ \\
\hline \multirow[t]{4}{*}{1994} & 1 & 0.3 & $0.4 \mathrm{a}$ & $0.31 \mathrm{a}$ & $0.05 a$ & $0.46 a b$ & $0.82 b$ & $98.9 \mathrm{a}$ \\
\hline & & 0.6 & $0.2 \mathrm{a}$ & $0.41 \mathrm{a}$ & $0.12 \mathrm{a}$ & $0.01 \mathrm{c}$ & $0.53 b$ & $92.4 \mathrm{~b}$ \\
\hline & & 0.8 & $1.2 \mathrm{a}$ & $0.45 \mathrm{a}$ & $0.10 \mathrm{a}$ & $0.08 b c$ & $0.64 b$ & $87.4 \mathrm{~b}$ \\
\hline & & 1.0 & $1.0 \mathrm{a}$ & $1.08 \mathrm{a}$ & $0.32 \mathrm{a}$ & $0.61 \mathrm{a}$ & $2.01 \mathrm{a}$ & $73.7 \mathrm{c}$ \\
\hline
\end{tabular}

${ }^{\mathrm{z} F o r}$ each harvest, values sharing a letter are not significantly different $(\alpha=0.05)$ based on Duncan's mulriple range test. yFor each harvest, values sharing a letter are not significantly different $(\alpha=0.05)$ based on honestly significant intervals.

R.G. Allen (eds.). ASCE manuals and reports on engineering practice no. 70. Amer. Soc. Civil Eng., New York.

Barger, W.R., B.A. Friedman, W.A. Radspinner, and L.L. Morris. 1952. Shipping tests with California mature-green tomatoes fall 1951. U.S. Dept. of Agr., Agr. Res. Admin., Bur. of Plant Ind., Soils, and Agr. Eng. Div. of Handling, Transportation, and Storage of Hort. Crops Office Rpt. no. 286.

Burgis, D.S. 1970. Fruit chilling and ripening studies for evaluation of breeding lines of fresh market tomatoes. Proc. Fla. State Hort. Soc. 83:135-137.

Conseil des productions végétales du Québec (CPVQ). 1978. Légumes. Culture. Ministère de l'Agriculture du Québec, Québec.

Dodds, G.T. 1991. Colour changes during chilling of tomato (Lycopersicon esculentum Mill.) fruit, surface topology of injury and some physiological changes. PhD thesis. Cornell Univ., Ithaca, N.Y.

Dodds, G.T., J.W. Brown, and P.M. Ludford. 1991. Surface color changes of tomato and other solanaceous fruit during chilling. J. Amer. Soc. Hort. Sci. 116:482-490.

Dodds, G.T. and P.M. Ludford. 1989. Surface topology of chilling injury of tomato fruit. HortScience 25:1416-1419.

Doorenbos, J. and A.H. Kassam. 1979. Yield response to water. FAO Irr. Drainage Paper 33:157-160.

Doty, C. 1983. Considerations for the design and operation of controlled drainage subirrigation systems. Amer. Soc. of Agr. Eng. Paper no. 832566. Amer. Soc. Agr. Eng.,St. Joseph, Mich.

Duncan, D.B. 1955. Multiple range and multiple $F$ tests. Biometrics 11:142.

Hobson, G.E. 1987. Low-temperature injury and the storage of ripening tomatoes. J. Hort. Sci. 62:55-62.

Hubbell, J.N., R.D. William, S.M. Lin, Y.S.C. Roan, and H.A. Hsu. 1979. Effect of excessive water, cultivar, compost, and BA and performance of tomato production on two soil types, p. 154-166. In: R. Cowell (ed.). First International Symposium on Tropical Tomato. Asian Veg. Res. and Dev. Centre, Shanhua, Taiwan.

Kader, A.A. and L.L. Morris. 1975. Amelioration of chilling injury symptoms on tomato fruit. HortScience 10:324 (Abstr.)

Kalita, P.K. and R.S. Kanwar. 1993. Effects of watertable management on the transport of nitrate-N to shallow groundwater. Trans. Amer. Soc. Agr. Eng. 36:413-422.

Kawada, K., W. Grierson, and J. Soule. 1978. Seasonal resistance to chilling injury of 'Marsh' grapefruit as related to winter field temperature. Proc. Fla. State Hort. Soc. 91:128-130.

Kidd, F. and C. West. 1933. Low-temperature tolerance of summer- and autumn-grown hot-house tomatoes. Rpt. Food Investigation Board 1932
(U.K.) p. $82-83$.

Lopez, M.V., and D.A. del Rosario. 1983. Performance of tomatoes [Lycopersicon lycopersicum (L.) Karsten] under waterlogged condition [sic]. Philippine J. Crop Sci. 8:75-80.

Madramootoo, C.A., G.T. Dodds, and A. Papadopoulos. 1993. Agronomic and environmental benefits of water-table management. J. Irr. Drain. Eng. 119:1052-1064.

Moline, H.E. 1980. Effects of vacuum infiltration of calcium chloride on ripening rate and chilling injury of tomato fruit. Phytopathology 70:691.

Monselise, S.P. and R. Goren. 1987. Preharvest growing conditions and postharvest behavior of subtropical and temperate-zone fruit. HortScience 22:1185-1189.

Morris, L.L. 1953. Temperature in relation to the ripening behavior of tomato. p. 141-146. In: Proceedings - Conference on transportation of perishables, 5-7 Feb. 1953, Davis, Calif.

Morris, L.L. 1954. Field and transit chilling of fall grown tomatoes, p. 101-105. In: Proceedings-Conference on transportation of perishables, 26-28 Apr. 1954, Davis, Calif.

Orchard, P.W. and R.S. Jessop. 1984. The response of sorghum and sunflower to short-term waterlogging. I. Effects of stage of development and duration of waterlogging on growth and yield. Plant Soil 18:119132.

Rosa, J.T. 1926. Ripening and storage of tomatoes. Proc. Amer. Soc. Hort. Sci. 23:233-242.

Saltveit, Jr., M.E. 1991. Prior temperature exposure affects susbsequent chilling sensitivity. Physiol. Plant. 82:529-536.

Saltveit, Jr., M.E. and R.M. Cabrera. 1987. Tomato fruit temperature before chilling influences ripening after chilling. HortScience 22:452454.

Sharples, R.O. 1985. The influence of preharvest conditions on the quality of stored fruits. Acta Hort. 157:93-104.

Stone, K. and G. Williams. 1992. Watertable management in Eastern coastal plains. J. of Soil and Water Conservation 47:47-51.

Topp, G.C. and J.L. Davis. 1985. Time domain reflectometry (TDR) and its application to irrigation scheduling. Advances in Irr. 3:107-127.

Wardlaw, C.W. and L.P. McGuire. 1932. The storage of tropically-grown tomatoes. Empire Mkt. Board Rpt. 59, His Majesty's Stationery Office, London.

Wardlaw, C.W. and L.P. McGuire. 1933. Tomato storage-Further observations on the storage of tropically-grown tomatoes. Trop. Agr. 10:161-163.

Yourstone, K.S. and D.H. Wallace. 1990. Effects of photoperiod and temperature on rate of node development in indeterminate bean. J. Amer. Soc. Hort. Sci. 115:824-828. 